\section{Effects of Glucosinolates Rich Broccoli extract against Triazophos induced Toxicity in Wistar Rats}

\section{Abstract}

Background: Triazophos (TZ), an organophosphate (OP) pesticide, is widely used as non-systemic broad spectrum pesticide against insect pests. OPs, apart from neurotoxicity and neurobehavioral changes in animals, have been shown to induce oxidative stress (OS) by generating elevated levels of reactive oxygen species (ROS) which culminates into oxidative stress (OS).

Methods: Present study was carried out to evaluate the efficacy of antioxidative potential of glucosinolates rich broccoli $(\mathrm{Br})$ extract via three doses viz; 10,20 and $30 \mu \mathrm{mol}$, against the toxic effects of $1 / 10$ th of LD50 of TZ dose and its reversal in female albino rats during 30 days experiment. TZ induced OS biomarkers of blood toxicity viz; catalase (CAT), superoxide dismutase (SOD), glutathione reductase (GR), glutathione peroxidase (GPX), glutathione-S-transferase (GST), total antioxidant activity (AOA) and lipid peroxidation (LPO) were estimated.

Results: OS biomarkers such as CAT, SOD, GR and GPx were differentially modified in TZ treated female albino rats and were improved with broccoli supplementation alongwith TZ. The total antioxidant activity (AOA) was also significantly increased in plasma of all the treated rats $(\mathrm{Br}+\mathrm{TZ})$; while significantly reduced LPO levels were observed in all $\mathrm{Br}+\mathrm{TZ}$ treated rats as compared to $\mathrm{TZ}$ treated rats.

Conclusion: Subtly improved CAT, SOD and GPx stress biomarkers alongwith reduced $L P O$ levels and enhanced $A O A$ suggest that the exposure of female albino rats to TZ may be reversed by antioxidant potential of broccoli extract.

Keywords: Blood; Broccoli extract; Oxidative stress; Reactive oxygen species; Triazophos

\section{Dharmender Sharma and Gurinder Kaur Sangha \\ Department of Zoology, Punjab Agricultural University, Ludhiana-141004, India}

\section{Corresponding author:}

Dharmender Sharma

\section{झ dsk686@gmail.com}

Phd Scholar, Department of Zoology, Punjab Agricultural University, Ludhiana-141004, India.

Citation: Sharma D, Sangha GK. Effects of Glucosinolates Rich Broccoli extract against Triazophos induced Toxicity in Wistar Rats. A Randomized Control Study. J Biomedical Sci. 2016, 5:4.

Received: June 21, 2016; Accepted: July 13, 2016; Published: July 19, 2016

\section{Introduction}

Pesticides intended for agricultural and other domestic practices not only produce adverse biological effects against the target species but also have the potential to affect the health of nontarget species including human beings, through the production of Reactive Oxygen Species (ROS) which ultimately lead to a condition of oxidative stress (OS) [1,2]. The ROS and Free Radicals (FR) have the ability to cause peroxidation of unsaturated lipids constituting the membrane of cells and depletion of cellular reserves of reducing elements (both enzymatic and nonenzymatic which jointly constitutes antioxidants defense system). Free Radicals with unpaired electrons have various chemical forms such as hydroxyl, superoxide, nitric oxide and lipid peroxyl radicals etc. and the production of $F R$ has been used in the genesis of toxicity of many man-made chemicals and drugs. OS occurs when production of ROS overrides antioxidant capacity in target cells, resulting in the damage of macromolecules such as nucleic acids, lipids and proteins which ultimately culminates into the biochemical and physiological constraints associated with healthy life [2].

Organophosphorus (OP) pesticides exposure is a major public health issue as OPs account for over $50 \%$ of all insecticides applied world-wide. Although organophosphates degrade faster than the pesticides, they have greater acute toxicity, posing risks to people who may be exposed to its large amounts. Some of the commonly used organophosphates include parathion, malathion, methyl parathion, chlorpyrifos, diazinon, dichlorvos, phosmet, 
tetrachlorvinphos, and azinphos methyl [2,3]. Organophosphates are potent nerve agents, as they act by inhibiting the action of AChE activity in nerve cells and are one of the most common causes of poisoning worldwide due to their easy availability and low cost. Their toxicity is not limited to the acute phase, however, their chronic effects have long been noted [2]. Triazophos, 0,0-diethyl-1-H-1,2,4-triazol-3-yl phosphorothioate, (TZ) a non-systemic broad spectrum OP is being extensively used against a wide range of pests and can potentially affect during its formulation, transport and storage [3]. OS has been evidenced in cells by the increased level of malondialdehyde (MDA) (end product of lipid peroxidation) and by differentially modified endogenous antioxidants like catalase (CAT), Glutathione-STransferase (GST), Superoxide Dismutase (SOD) and Glutathione Peroxidase (GPx), which can lead to development of moderate to severe pathophysiological consequences $[4,5]$.

Plant extracts derived from fruits and vegetables with natural antioxidative properties are traditionally used that slows down the process of oxidative damage caused by Reactive Oxygen Species (ROS) and strengthens the natural immune defences $[6,7]$. The glucosinolates are found in high concentration in many cruciferous vegetables and it is well established that their breakdown products induce endogenous antioxidant defences in cells in vitro and in vivo. Also Glucosinolates (GSL) have been shown to provide protection from oxidative stress through the elimination of ROS $[8,9]$. The cultivated Brassicaceae, broccoli ( $\mathrm{Br})$ has shown great anticarcinogenic and antioxidative properties and plays an important role in the detoxification when assimilated with diet [10]. In recent years, there has been a strong focus on health benefits of broccoli sprouts and extracts of sprouts in addition of whole broccoli, because of the high contents of GSLs in sprouts as compared to mature broccoli [11].

Earlier findings have indicated that certain varieties of broccoli sprouts contain remarkably high levels of glucoraphanin, the glucosinolate precursor of Sulforaphane (SFN) and may provide an efficient source of dietary glucoraphanin having strong antioxidising potential, which can be utilized for xenobiotic detoxification as well as the restoration of normal cellular activities [11]. Studies with laboratory animals regarding toxicokinetics and oxidative stress induction by TZ have been reported in female rats $[4,5]$. Present investigation was designed to check and evaluate the antioxidative efficacy of glucosinolates rich broccoli extract in ameliorating the TZ induced toxicity in female albino rats.

\section{Material and Methods}

\section{Chemicals}

All chemicals were purchased from Sigma-Aldrich, SDFCL (SD Fine-Chem Ltd), SRL (Sissco Research Laboratories Pvt. Ltd). All chemical used were either of analytical grade or the highest purity commercially available. Triazophos as Truzo 40 EC was obtained from Meghmani Organics Limited, Chharodi, India. Standard rat feed was purchased from Ashirwad Industries, Mohali, India.

\section{Plant source and Broccoli extract preparation}

Punjab Broccoli 1 (Brassica oleraceae var. italica) seeds were obtained from Department of Vegetable Sciences, Punjab
Agricultural University, Ludhiana. Seeds were surface-sterilized by a 1 -min rinse in $70 \%$ ethanol, a $15-\mathrm{min}$ exposure to $1.3 \%$ sodium hypochlorite and rinsing with distilled water and sprouts were produced. Sprouts were grown without added nutrients in inclined perforated trays $(35 \times 40 \mathrm{~cm})$ watered with four $15-\mathrm{s}$ gentle spray cycles per hour, with a 16 hour light and 8 hour dark photoperiod and temperature from $25^{\circ} \mathrm{C}$ to $27^{\circ} \mathrm{C}$. Sprouts were harvested gently on $1,3,5,8$ and 10 days from the tray and were freeze dried at $-80^{\circ} \mathrm{C}$ immediately to prevent the conversion of glucosinolates into isothiocyanates by the myrosinase.

Broccoli sprouts were rapidly plunged into 5 volume of boiling water and boiling was continued for $3 \mathrm{~min}$. The mixture was then cooled, filtered, and lyophilized to provide a dry powder. To $0.2 \mathrm{ml}$ of crude GSL extract containing $200 \mathrm{mg}$ powder, $0.3 \mathrm{ml}$ of distilled water and $3 \mathrm{ml}$ of $2 \mathrm{mM}$ palladium (II) chloride reagent were added and mixed. After incubation at $25^{\circ} \mathrm{C}$ for $1 \mathrm{hr}$, absorbance at $425 \mathrm{~nm}$ was measured using a spectrophotometer. Absorbance was shown by an average of three measurements and was used for estimation of total GSL contents [12]. For comparison with values of the total GSLs obtained using the palladium colorimetric method, an average of duplicated analyses for each plant was used and 5 days old plants were found to be containing highest concentrations of GSLs.

The GSL contents were inferred as the average of $200 \mathrm{mg}$ freeze dried samples in case of each sprouts and total GSLs concentrations were obtained as in $\mu \mathrm{mol} / \mathrm{gm}$. Subsequently three doses viz; 10, 20 and $30 \mu \mathrm{mol}$ of GSLs rich broccoli extract were prepared through known volume of water, and extract was obtained with GSLs concentration in 150-200 $\mu$ l range of extract and was deep freezed for further dosing through oral intubation against the 1/10th of LD50 TZ induced toxicity.

\section{Animals}

The female albino rats aging 9-12 weeks and weighing 140170 grams were procured from the Department of Livestock Production and Management, GADVASU, Ludhiana. Rats were housed in polypropylene cages (two rats in each cage) using paddy husk bedding in laboratory, where the humidity ( $55 \pm 5 \%$ ), temperature $\left(25 \pm 2^{\circ} \mathrm{C}\right)$ and normal photoperiod of 12 to 12 hours light-dark cycle were environmentally controlled. Rats were provided with laboratory standard rat feed and water ad libitum. All methods and procedures of animal handling during research were conducted in accordance with the guidelines of Committee for the Purpose of Control and Supervision of Experiments on Animals (CPCSEA), India and experiments conducted in the present study were duly approved by Institutional Animal Ethics Committee (IAEC), Guru Angad Dev Veterinary and Animal Sciences University, Ludhiana vide letter no. 3901-35 dated 06.08.2012.

\section{Experimental design}

Female albino rats were acclimatized for ten days in laboratory conditions and were divided into six groups with eight rats in each group during 30 days experiment.

Group I (Control) animals received olive oil + distilled water and served as control 
Group II (Br) only $10 \mu \mathrm{mol}$ glucosinolates (GSL) broccoli extract

Group III (TZ) TZ at the dose of 1/10th of LD50 in olive oil

Group IV (Br1+TZ) TZ in olive oil + $30 \mu \mathrm{mol}$ GSL broccoli extract

Group V (Br2+TZ) TZ in olive oil + $20 \mu \mathrm{mol}$ GSL broccoli extract

Group VI (Br3+TZ) TZ in olive oil + $10 \mu \mathrm{mol}$ GSL broccoli extract

The rats of $\mathrm{Br}+\mathrm{TZ}$ group were provided with broccoli extract in the morning and TZ was given in the evening at a difference of 12 hours. All treatments were carried out for 30 days by oral intubation. The rats were examined daily for feed intake, water intake and weekly for body weights. The signs of toxicity and mortality during dosing were also recorded.

\section{Organs weight and blood hemolysate preparation}

After 30 days of treatment, the rats were fasted overnight and were anaesthetized using chloroform before dissection. After dissection, blood sample from each rat was collected immediately directly from heart in heparinised vials and centrifuged at 2300 rpm. for 15 minutes. Supernatant was obtained as plasma for biochemical analysis and pellet i.e. Packed Cell Volume (PCV), was lysed in distilled water and $100 \%$ haemolysate was prepared for biochemical parameters. Various vital organs (stomach, heart and lungs) and endocrine glands (thyroid, parathyroid and adrenals) were excised, cleared off the adhering tissue and weighed.

\section{Biochemical Studies}

\section{Biochemical parameters of blood were assayed by standard methods}

Estimation of proteins: Total proteins were estimated by method of Lowry et al. [13] and after mixing all reagents, absorbance was recorded at $520 \mathrm{~nm}$ in a spectrophotometer against reagent blank. A standard curve was prepared by taking BSA solution in range of $20-200 \mu \mathrm{g} / \mathrm{ml}$ and after calculation units were expressed as $\mathrm{g} / \mathrm{dL}$ sample.

Assay of catalase (CAT): The activity of catalase in haemolysate was determined according to method described by Aebi [14]. Decrease in absorbance was recorded at $10 \mathrm{sec}$ interval for 1 $\min$ at $240 \mathrm{~nm}$ in a U.V. spectrophotometer. The results were expressed as $\mu \mathrm{mol} \mathrm{H}_{2} \mathrm{O}_{2}$. decomposed per min per mg $\mathrm{Hb}$ using 36 as molar extinction coefficient of $\mathrm{H}_{2} \mathrm{O}_{2}$.

Assay of superoxide dismutase (SOD): The activity of Superoxide Dismutase (SOD) in haemolysate was determined by the method of Marklund and Marklund [15]. The rate of auto-oxidation of pyrogallol was taken from the increase in absorbance at 420 $\mathrm{nm}$ in a spectrophotometer, every min after a lag of $30 \mathrm{sec}$ upto $4 \mathrm{~min}$. For the test, $20 \mu \mathrm{l}$ of enzyme preparation was added to inhibit the auto-oxidation of pyrogallol to about $50 \%$. A unit of enzyme activity was defined as the amount of enzyme causing $50 \%$ inhibition of the auto-oxidation of pyrogallol observed in blank. The values were expressed as units/mg protein.

Assay of Glutathione-S-Transferase (GST): The activity of Glutathione-S-Transferase (GST) in haemolysate was determined by the method given by Habig et al. [16]. The increase in optical density at $340 \mathrm{~nm}$ in a spectrophotometer was recorded for 3 min, after a lag of $30 \mathrm{sec}$. The extinction coefficient of CDNB conjugate at $340 \mathrm{~nm}$ is $9.6 / \mathrm{mm} / \mathrm{cm}$. The activity was expressed as $\mu$ moles of GSH-CDNB conjugate formed $/ \mathrm{min} / \mathrm{mg}$ protein.

Assay of glutathione reductase (GR): The assay of Glutathione Reductase (GR) was performed according to the method described by Carlberg and Mannervik [17]. Decrease in absorbance at 340 $\mathrm{nm}$ was recorded at $30 \mathrm{sec}$ interval for $3 \mathrm{~min}$. A unit of glutathione reductase activity was defined as the amount of enzyme that catalyzes the oxidation of $1 \mu \mathrm{mol}$ of NADPH/min using $6.22 \times$ $10^{3}$ as molar extinction coefficient of NADPH. The activity was expressed as $\mu$ moles of NADPH oxidized/min/mg protein.

Assay of glutathione peroxidise (GPx): The activity of glutathione peroxidase in haemolysate was assayed by the method of Hafeman et al. [18]. Optical density was recorded at $412 \mathrm{~nm}$ within two minutes after mixing all the reagents with sample. The zero time GSH concentration was determined in the same manner using an aliquot from a sample treated similarily but containing water in place of $\mathrm{H}_{2} \mathrm{O}_{2}$.

Activity of GPx $=10 \log \mathrm{Co} / \mathrm{C}$

Co = concentration of GSH at zero time.

$\mathrm{C}=$ concentration of GSH after 1 min incubation. The activity was expressed as units/mg protein.

Estimation of lipid peroxidation (LPO): Lipid peroxidation in haemolysate was assayed by the method of Stocks and Dormandy [19]. The method is based on the principle that the reaction of Malondialdehyde (MDA), an end point of lipid peroxidation, with thiobarbituric acid (TBA) yielded a pink coloured trimethine complex exhibiting an absorption maximum at $532 \mathrm{~nm}$. Units were expressed as $\mathrm{nM} \mathrm{MDA} / \mathrm{ml}$ sample.

Total antioxidant activity (AOA): Total antioxidant activity (AOA) in plasma was estimated by Koracevic et al. [20] method. After mixing all reagents with plasma absorbance was recorded at 532 $\mathrm{nm}$ against deionised water and units were expressed as $\mathrm{mmol} /$ $\mathrm{ml}$ sample.

\section{Statistical Analysis}

The experimental results are expressed as mean \pm standard error of the mean (SEM) for $n=8$. Statistical analysis of data was performed on computer by using CPCS1. One-way ANOVA was done to check any significance and the criterion for statistical significance was set at $\mathrm{P}<0.05$.

\section{Results and Discussion}

Organophosphates (OPs) due to their effectiveness, low cost and easy availability, are the most widely used pesticides in agricultural practices. But due to their irrational use, OPs induce cholinergic poisoning and also have been shown to induce oxidative stress with enhanced generation of ROS [21]. Natural antioxidants, especially glucosinolates, have been found to be a promising antioxidant agent that is effective to attenuate oxidative stress and tissue/cell damage as a result of the toxic manifestations of xenobiotic compounds in the living systems [22]. 
In our present investigation, daily water intake (Figure 1) and feed intake (Figure 2) during 30 days of treatment was decreased in TZ group rats as compared to control rats, while broccoli extract supplementation resulted in increased water and feed intake in all the $\mathrm{Br}+\mathrm{TZ}$ treatment groups as compared to $\mathrm{TZ}$ female rat group, though results were non significant at $P \leq 0.05$. Increased water and feed intake in all the $\mathrm{Br}+\mathrm{TZ}$ treatment groups can be due to adaptation of mammalian system against the TZ and broccoli extract supplementation, and broccoli extract has shown the effective preliminary response to counter the toxicity being induced by TZ. Similarly broccoli extract has been found to be antioxidant rich supplement and inducer of physiological pathways against the number of chemical substances, which ultimately tries to restores the normal metabolic activities in the living models $[8,9,23,24]$ and these findings corroborates present investigation.
In toxicological studies, organ and relative organ weights are important criteria for evaluation of toxicity [23]. Reduced body weight gain was observed in TZ treated rats and was improved non significantly in all $\mathrm{Br}+\mathrm{TZ}$ treated group rats (Table 1). Improved body weight in all $\mathrm{Br}+\mathrm{TZ}$ treated group rats may be attributed to slightly restored feed intake or food palatability as compared to treatment related toxicity in TZ group rats [4], due to treatment with GSL rich Broccoli extract, which might have decreased the oxidative stress and has improved the metabolic process of triazophos treated rats, and food palatability, feed intake and consequently their body weight were improved. The ameliorative potential of broccoli extract is further supported by the study where other natural antioxidants such as vitamin $\mathrm{E}$, having antioxative property, was assessed against malathion induced toxicity in rats, and body weights were significantly improved [25]. Co-treatment of TZ exposed rats with broccoli

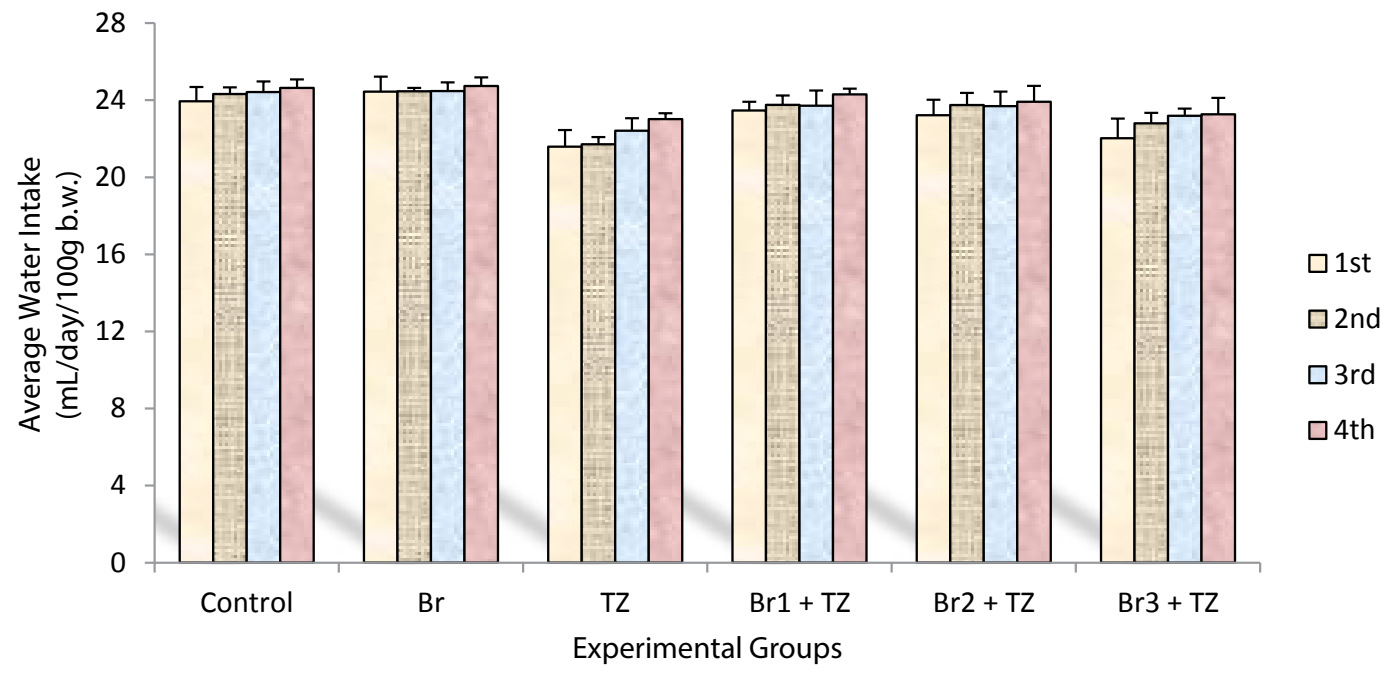

Figure 1 Weaning time in both groups

Values expressed as Mean \pm SE $(n=8)$.

*Significant difference $(P \leq 0.05)$ as compared to control

^Significant difference $(P \leq 0.05)$ as compared to $T Z$

(Abbreviations: $\mathrm{Br}$ : broccoli; $\mathrm{TZ}$ : triazophos; $\mathrm{Br}+\mathrm{TZ}$ : broccoli plus triazophos)

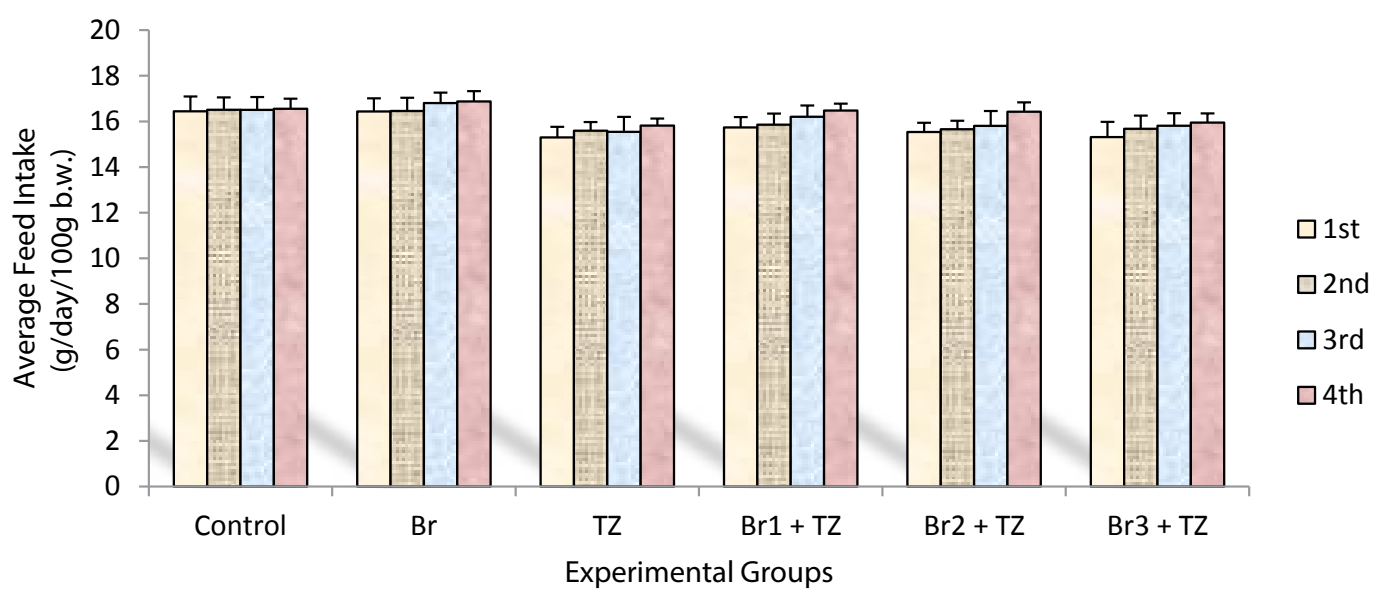

Figure 2 Effect of Triazophos and Broccoli extract on Average feed intake (g/100 g b.w.) in control and treated female Wistar rats after 1, 2, 3 and 4 weeks of treatment. 
combination showed slightly increased relative weights of lungs and stomach as compared to TZ group rats (Table 2 ), while the weight of endocrine glands was comparable (Table 2). Significantly decreased thyroid weight was observed in TZ along with 30 and $20 \mu \mathrm{mol}$ GSL Broccoli extract treated rats, which might be due to result of adaptation of rats body to sub-chronic exposure of both agents at higher concentrations. Slight hyperirritability and loose faecal pellets were observed in TZ group rats, while all $\mathrm{Br}+\mathrm{TZ}$ treated group rats showed normal natural behavior and no excessive salivation was reported. These parameters might have been improved by the protective potential of broccoli extract in $\mathrm{Br}+\mathrm{TZ}$ group rats and rats were reported to be normal and naturally active during the co-treatments of TZ and extract.

Protective antioxidative potential of large number of natural extracts have been reported, which tries to restore stress biomarkers status in vivo $[9,24,25]$. The amount of proteins in blood hemolysate (Table 3) and plasma (Figure 3) of all group rats was comparable. Present study revealed significantly higher CAT activity levels in TZ group treated rats as compared to control, while these were significantly restored in all the $\mathrm{Br}+\mathrm{TZ}$ group rats in comparison to TZ group rats at $P \leq 0.05$ (Table 3 ). Significantly lowered activity levels of SOD in TZ group rats were noticed and SOD activity was slightly improved in all the $\mathrm{Br}+\mathrm{TZ}$ group rats (Table 3 ). GST activity levels were non significantly elevated in $\mathrm{TZ}$ as well as $\mathrm{Br}+\mathrm{TZ}$ group rats at $\mathrm{P} \leq 0.05$ to the control rats (Table 3 ). Present investigation further revealed the enhanced levels of GPx in TZ and all $\mathrm{Br}+\mathrm{TZ}$ group rats as compared to control rats. The activity levels of GPx were lowered in $\mathrm{Br}+\mathrm{TZ}$ group rats, though these were non significant at $\mathrm{P} \leq 0.05$ to the TZ rats (Table 3 ). GR activity was increased in TZ treated rats in contrast to control rats and was statistically significant. Subsequently, GR activity was significantly high in all $\mathrm{Br}+\mathrm{TZ}$ group rats as compared to TZ group rats (Table 3 ). Among these stress biomarkers, significantly higher activity levels of CAT, GPx and GR were reported, while significantly lowered activity levels of SOD in TZ group rats were observed as compared to the $\mathrm{Br}+\mathrm{TZ}$ group rats. These stress biomarkers were subtly restored in all the $\mathrm{Br}+\mathrm{TZ}$ group rats. Similar observations have been reported in blood erythrocytes of chlorpyrifos treated rats for SOD and

Table 1 Effect of Triazophos and Broccoli extract treatment on Body Weight (bw) of treated female albino rats as compared to control rats.

\begin{tabular}{|c|c|c|c|c|c|c|}
\hline & Control & $\mathrm{Br}$ & $\mathrm{TZ}$ & $\mathrm{Br} 1+\mathrm{TZ}$ & $\mathrm{Br}+\mathrm{TZ}$ & $\mathrm{Br3}+\mathrm{TZ}$ \\
\hline Initial b.w. (g) & $161.75 \pm 4.19$ & $162.50 \pm 5.76$ & $163.52 \pm 4.57$ & $164.75 \pm 5.03$ & $164.50 \pm 3.87$ & $160.75 \pm 4.84$ \\
\hline Final b.w. (g) & $195.50 \pm 4.145$ & $196.75 \pm 5.31$ & $190.45 \pm 3.43$ & $193.50 \pm 4.11$ & $195.75 \pm 3.21$ & $187.72 \pm 3.67$ \\
\hline B.W. gain (\%) & $20.87 \pm 1.23$ & $21.09 \pm 0.94$ & $16.58 \pm 1.01$ & $17.47 \pm 1.14$ & $18.43 \pm 1.03$ & $16.79 \pm 1.23$ \\
\hline
\end{tabular}

(Abbreviations: Br: broccoli; TZ: triazophos; $\mathrm{Br}+\mathrm{TZ}$ : broccoli plus triazophos)

Values expressed as Mean \pm SE $(n=8)$.

*Significant difference $(P \leq 0.05)$ as compared to control

^Significant difference $(\mathrm{P} \leq 0.05)$ as compared to $T Z$

Table 2 Effect of Triazophos and Broccoli extract treatment on Organs Weight ( $\mathrm{g} / 100 \mathrm{~g}$ bw) of treated female albino rats as compared to control.

\begin{tabular}{|c|c|c|c|c|c|c|}
\hline & Control & $\mathrm{Br}$ & $\mathrm{TZ}$ & $\mathrm{Br}+\mathrm{TZ}$ & $\mathrm{Br}+\mathrm{TZ}$ & $\mathrm{Br}+\mathrm{TZ}$ \\
\hline Stomach & $1.538 \pm 0.101$ & $1.662 \pm 0.057$ & $1.069 \pm 0.054^{*}$ & $1.805 \pm 0.051^{* \wedge}$ & $1.754 \pm 0.042^{* \wedge}$ & $1.627 \pm 0.086^{\wedge}$ \\
\hline Heart & $0.297 \pm 0.007$ & $0.307 \pm 0.005$ & $0.309 \pm 0.012$ & $0.306 \pm 0.010$ & $0.303 \pm 0.011$ & $0.305 \pm 0.009$ \\
\hline Lungs & $0.602 \pm 0.035$ & $0.689 \pm 0.021$ & $0.695 \pm 0.041$ & $0.768 \pm 0.061^{*}$ & $0.716 \pm 0.049 *$ & $0.696 \pm 0.042$ \\
\hline Thyroid & $0.106 \pm 0.004$ & $0.105 \pm 0.004$ & $0.099 \pm 0.013$ & $0.089 \pm 0.004^{*}$ & $0.093 \pm 0.005^{*}$ & $0.109 \pm 0.008$ \\
\hline Parathyroid & $0.045 \pm 0.001$ & $0.044 \pm 0.002$ & $0.039 \pm 0.004$ & $0.039 \pm 0.004$ & $0.039 \pm 0.002$ & $0.038 \pm 0.003$ \\
\hline Adrenal & $0.012 \pm 0.000$ & $0.014 \pm 0.000$ & $0.014 \pm 0.001$ & $0.012 \pm 0.001$ & $0.013 \pm 0.000$ & $0.015 \pm 0.001$ \\
\hline
\end{tabular}

(Abbreviations: $\mathrm{Br}$ : broccoli; $\mathrm{TZ}$ : triazophos; $\mathrm{Br}+\mathrm{TZ}$ : broccoli plus triazophos)

Values expressed as Mean \pm SE $(n=8)$.

* Significant difference $(P \leq 0.05)$ as compared to control

$\wedge$ Significant difference $(\mathrm{P} \leq 0.05)$ as compared to $\mathrm{TZ}$

Table 3 Effect of Triazophos and Broccoli extract treatment on Blood Biochemical parameters in female Wistar rats.

\begin{tabular}{|c|c|c|c|c|c|c|}
\hline & Control & $\mathrm{Br}$ & $\mathrm{TZ}$ & $\mathrm{Br} 1+\mathrm{TZ}$ & $\mathrm{Br}+\mathrm{TZ}$ & $\mathrm{Br3}+\mathrm{TZ}$ \\
\hline Protein & $16.83 \pm 0.53$ & $16.57 \pm 0.39$ & $17.33 \pm 0.23$ & $17.59 \pm 0.33$ & $17.16 \pm 0.23$ & $17.14 \pm 0.31$ \\
\hline CAT & $13.21 \pm 0.24$ & $14.24 \pm 0.09$ & $24.37 \pm 0.41^{*}$ & $16.83 \pm 0.82^{\wedge}$ & $15.64 \pm 0.25^{\wedge}$ & $17.27 \pm 0.58^{\wedge}$ \\
\hline SOD & $9.65 \pm 0.45$ & $9.56 \pm 0.22$ & $5.44 \pm 0.33^{*}$ & $6.33 \pm 0.47^{*}$ & $5.98 \pm 0.27^{*}$ & $5.49 \pm 0.12^{*}$ \\
\hline GST & $0.015 \pm 0.001$ & $0.014 \pm 0.001$ & $0.017 \pm 0.000$ & $0.017 \pm 0.001$ & $0.019 \pm 0.001$ & $0.019 \pm 0.002$ \\
\hline GPx & $2.66 \pm 0.06$ & $2.72 \pm 0.05$ & $4.34 \pm 0.07 *$ & $3.37 \pm 0.09^{*}$ & $3.41 \pm 0.08^{*}$ & $3.58 \pm 0.22^{*}$ \\
\hline GR & $0.004 \pm 0.000$ & $0.006 \pm 0.001$ & $0.008 \pm 0.001 *$ & $0.013 \pm 0.001^{*}$ & $0.016 \pm 0.002^{* \wedge}$ & $0.016 \pm 0.001^{* \wedge}$ \\
\hline
\end{tabular}

Units: Proteins (g/dL sample), CAT ( $\mu$ mole of $\mathrm{H}_{2} \mathrm{O}_{2}$ decomposed/min/mg protein), SOD (U/mg protein), GST ( $\mu$ moles of GSH-CDNB conjugate formed/ $\mathrm{min} / \mathrm{mg}$ protein), GR ( $\mu$ moles of NADPH oxidized/ $\mathrm{min} / \mathrm{mg}$ protein), GPx (U/mg protein). Values expressed as Mean $\pm \mathrm{SE}(\mathrm{n}=8)$.

*Significant difference $(P \leq 0.05)$ as compared to control

$\wedge$ Significant difference $(\mathrm{P} \leq 0.05)$ as compared to $\mathrm{TZ}$

(Abbreviations: $\mathrm{Br}$ : broccoli; TZ: triazophos; $\mathrm{Br}+\mathrm{TZ}$ : broccoli plus triazophos) 
GST, where supplementation of antioxidant was found with protective antioxidising potential [26], further supports present study.Antioxidant capacity is an important factor to assess normal physiological standards in animals [27]. Total antioxidant activity (AOA) was restored significantly in all $\mathrm{Br}+\mathrm{TZ}$ group rats as compared to $\mathrm{TZ}$ group rats and was comparable to control rats (Figure 4) and is also in agreement with number of studies, where OPs exposure leads to decreased total antioxidant activity [28] and it was improved with the broccoli supplementation, further suggests strong antioxidising potential of broccoli extract against pesticide. OPs intoxication is associated with the generation of ROSs, and ROSs are mainly responsible for LPO, thus leading to enhanced MDA levels in blood [29]. Malondialdehyde (MDA) is an end product of lipid peroxidation of phospholipids in the cell membrane and the enhanced levels of MDA is an indicator of oxidative stress. MDA levels were also high in the OPs treated rats as compared to control rats [29]. Lipid peroxidation in terms of MDA levels were subtly reduced in all $\mathrm{Br}+\mathrm{TZ}$ treated group rats as compared to TZ group rats. Co-treatment of 30 and $20 \mu \mathrm{mol}$ of GSLs rich broccoli extract with TZ have significantly reduced the MDA levels as compared to the TZ treated rats at $P \leq 0.05$ (Figure 5). Reduced MDA levels in all $\mathrm{Br}+\mathrm{TZ}$ treated group rats, suggests that TZ act as a catalyst in the induction of oxidative stress and this effect was minimized by the treatment with the GSL rich broccoli extract.

The increased activity of CAT seen in the poisoning cases coupled with an increase in the lipid peroxidation level (MDA) suggests an insufficient antioxidant defense which could be due to both

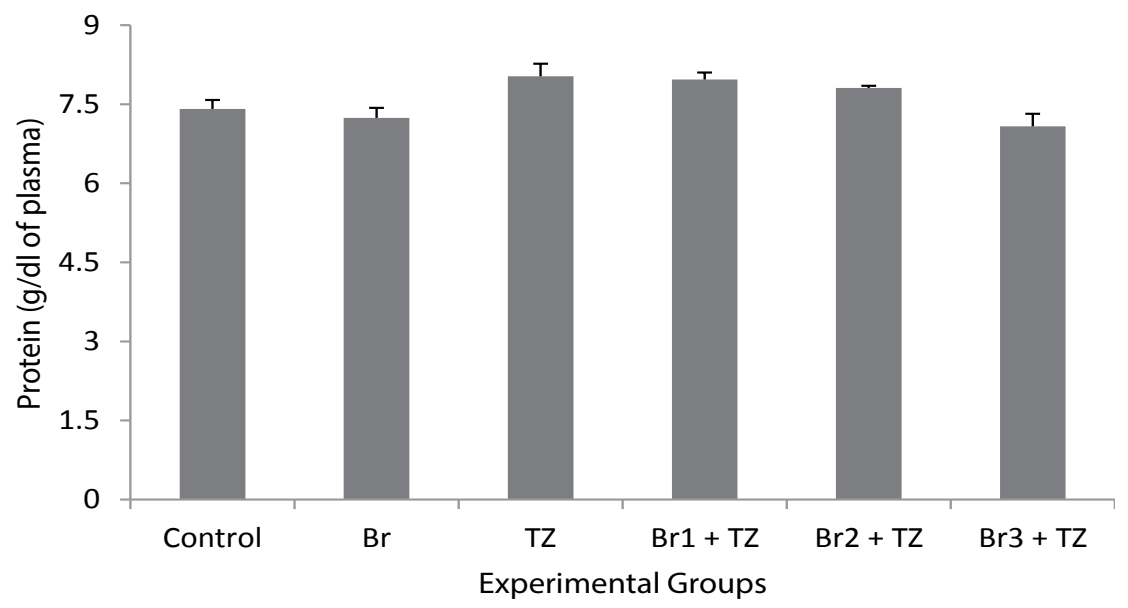

Figure 3 Effect of Triazophos and Broccoli extract treatment on Plasma Total protein. Values expressed as Mean \pm SE $(n=8)$.

*Significant difference $(P \leq 0.05)$ as compared to control

$\wedge$ Significant difference $(\mathrm{P} \leq 0.05)$ as compared to $\mathrm{TZ}$

(Abbreviations: $\mathrm{Br}$ : broccoli; $\mathrm{TZ}$ : triazophos; $\mathrm{Br}+\mathrm{TZ}$ : broccoli plus triazophos)

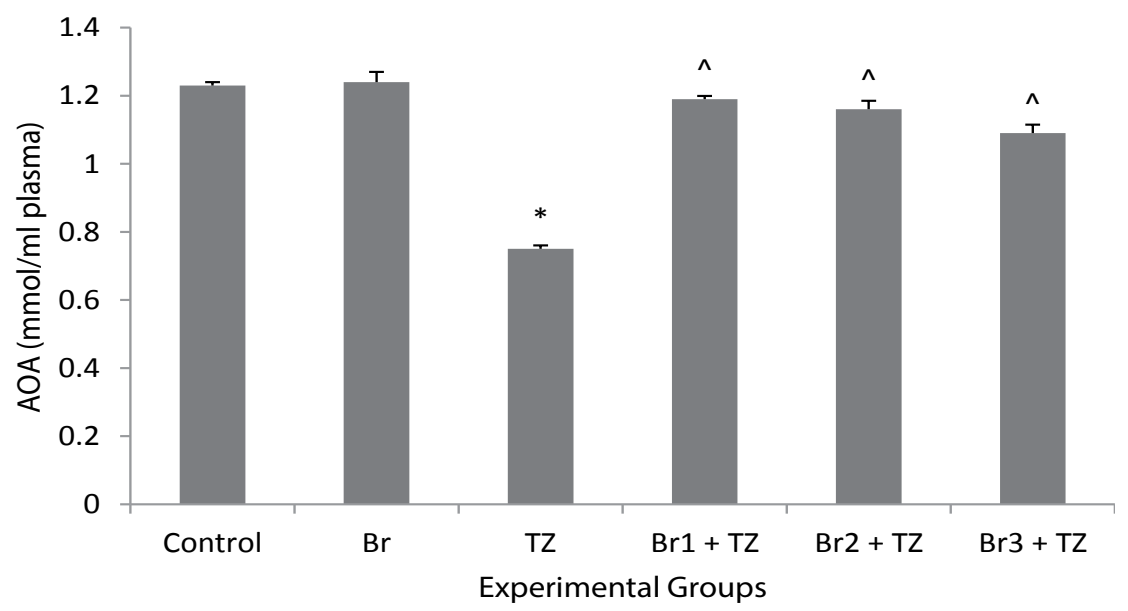

Figure 4 Effect of Triazophos and Broccoli extract treatment on Total Antioxidant activity (AOA) of Plasma.

Values expressed as Mean $\pm S E(n=8)$.

*Significant difference $(P \leq 0.05)$ as compared to control

$\wedge$ Significant difference $(P \leq 0.05)$ as compared to $T Z$

(Abbreviations: Br: broccoli; TZ: triazophos; $\mathrm{Br}+\mathrm{TZ}$ : broccoli plus triazophos) 
increase in pesticide-induced ROS formation and SOD inhibition [30]. Further natural antioxidants were found to be protective against chlorpyrifos induced toxicity, by reducing oxidative stress burden through reduced LPO levels in blood erythrocytes [26] also strengthens our findings. The increased levels of MDA and the decreased AOA along with reduced SOD activity may pose the survival threat to live cells, which may have the potential to affect various organs and their normal physiology leading to severe pathophysiological conditions. As triazophos and extract exposure was sub chronic and not induced severe effects. It might be due to the utilization of most of the SOD for the clearing of free radicals, while the expression of CAT and GPx was triggered to restore the integrity of biological system. LPO levels were improved in the rats intubated with extract along with $\mathrm{TZ}$, suggests protective behaviour of GSLs in the extract. Thus, present investigation indicates that GSL rich broccoli extract has the protective potential against the pesticides intoxication.

\section{Conclusion}

From above, it can be inferred that triazophos induced oxidative stress due to the sub chronic exposure of TZ on female rats, was assessed against the antioxidative potential of broccoli extract. Subtly improved CAT, SOD and GPx stress biomarkers alongwith reduced LPO levels and enhanced AOA suggest that the exposure of female albino rats to TZ may be reversed by antioxidant

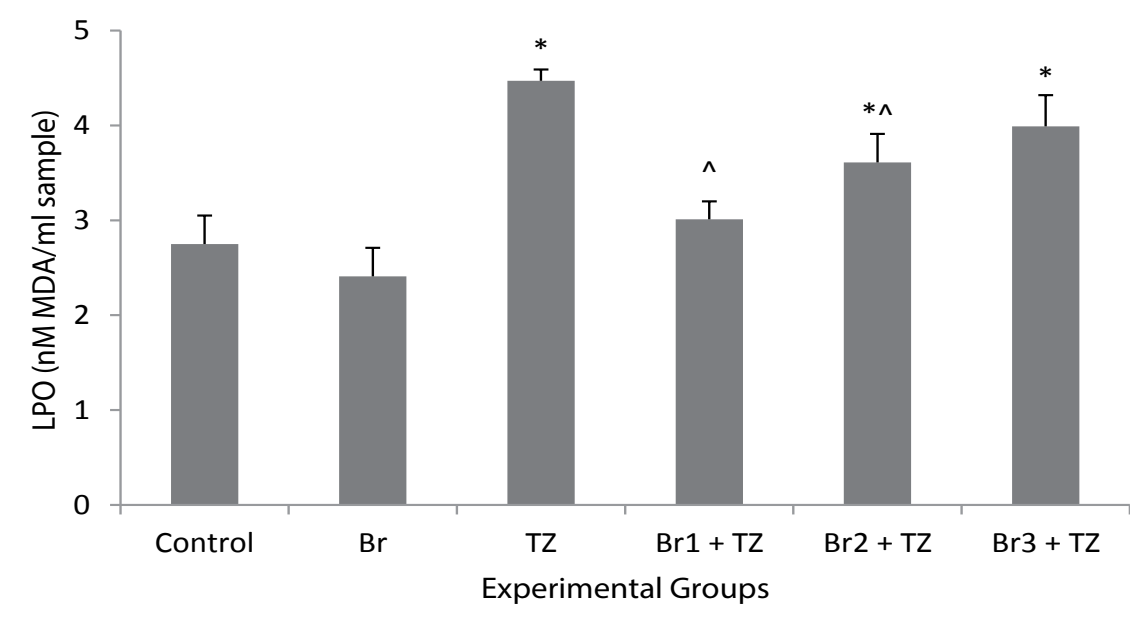

Figure 5 Effect of Triazophos and Broccoli extract treatment on Blood Lipid peroxidation (LPO) levels.

Values expressed as Mean $\pm S E(n=8)$.

*Significant difference $(P \leq 0.05)$ as compared to control

$\wedge$ Significant difference $(P \leq 0.05)$ as compared to $T Z$

(Abbreviations: $\mathrm{Br}$ : broccoli; $\mathrm{TZ}$ : triazophos; $\mathrm{Br}+\mathrm{TZ}$ : broccoli plus triazophos)

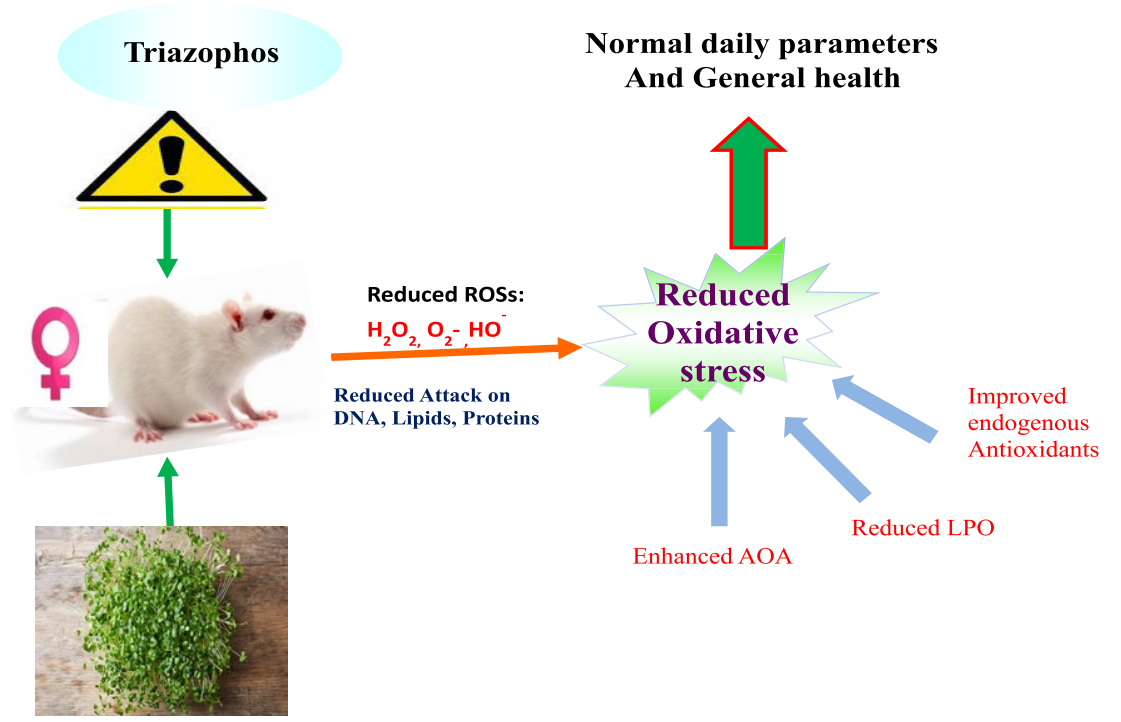

Figure 6 Effect of Triazophos and Broccoli extract treatment on Female rats. 
potential of broccoli extract (Figure 6), however, further studies at molecular level are needed, to elucidate mechanism underlying amelioration of oxidative stress with broccoli extract and for estimation of better doses of broccoli extract in the living system against pesticides.

\section{Acknowledgements}

The authors are thankful to the Head, Department of Zoology, Punjab Agricultural University, Ludhiana, Punjab (India) for providing necessary facilities to carry out the present investigation. 


\section{Refernces}

1 Antwi FB, Reddy GV (2015) Toxicological effects of pyrethroids on non-target aquatic insects. Environ Toxicol Pharmacol 40: 915-923.

2 Agrawal A, Sharma B (2010) Pesticides induced oxidative stress in mammalian systems: Review Article. Int J Biol Med Res 1: 90-104.

3 Li W, Qiu SP, Wu YJ (2008) Triazophos residues and dissipation rates in wheat crops and soil. Ecotoxicol Environ Saf 69: 312-316.

4 Sharma D, Sangha GK, Khera KS (2014) Triazophos induced oxidative stress in female albino rats. Int J Adv Res 2: 746-754.

5 Sharma D, Sangha GK (2014) Triazophos induced oxidative stress and histomorphological changes in liver and kidney of female albino rats. Pestic Biochem Physiol 110: 71-80.

6 Vouldoukis I, Lacan D, Kamate C, Coste P, Calenda A, et al. (2004) Antioxidant and anti-inflammatory properties of a Cucumis melo LC. extract rich in superoxide dismutase activity. J Ethnopharmacol 94: 67-75.

7 Murbach TS, Béres E, Vértesi A, Glávits R, Hirka G, et al. (2015) A comprehensive toxicological safety assessment of an aqueous extract of Polypodium leucotomos (Fernblock( $\left.{ }^{\circledast}\right)$ ). Food Chem Toxicol 86: 328-341.

8 Jeffery EH, Araya M (2009) Physiological effects of broccoli consumption. Phytochem Rev 8: 283-298.

9 Danesh E, Khatamsaz S, Shojaeifard M, Khabbaz Z (2014) Effects of hydro-alcoholic extract of broccoli (Brassica oleracea) on sensory threshold of pain using the formalin test in adult male rats. J Biol Today's World 3: 147-151.

10 Murashima M, Watanabe S, Zhuo XG, Uehara M, Kurashige A (2004) Phase 1 study of multiple biomarkers for metabolism and oxidative stress after one-week intake of broccoli sprouts. Biofactors 22: 271-275.

11 Fahey JW, Zhang Y, Talalay P (1997) Broccoli sprouts: an exceptionally rich source of inducers of enzymes that protect against chemical carcinogens. Proc Natl Acad Sci USA 94: 10367-72.

12 Moller P, Ploger A, Sørensen H (1985) Quantitative analysis of total glucosinolate content in concentrated extracts from double low rapeseed by the Pd-glucosinolate complex method. In: Sørensen $\mathrm{H}$., editor. (ed.) Advances in the Production and Utilization of Cruciferous Crop, Martinus Nijhoff/DR W. Junk Publishers, Dordrecht pp: 97-110.

13 Lowry OH, Rosebrough NJ, Farr AL, Randall RJ (1951) Protein measurement with the Folin phenol reagent. J Biol Chem 193: 265-275.

14 Aebi $\mathrm{H}$ (1983) Catalase methods in enzymatic analysis (ed) Bergmeryer HU, Academic Press, New York pp: 276-286.

15 Marklund S, Marklund G (1974) Involvement of the superoxide anion radical in the autoxidation of pyrogallol and a convenient assay for superoxide dismutase. Eur J Biochem 47: 469-474.

16 Habig WH, Pabst MJ, Jakoby WB (1974) Glutathione S-transferases.
The first enzymatic step in mercapturic acid formation. J Biol Chem 249: 7130-7139.

17 Carlberg I, Mannervik B (1985) Glutathione reductase. Methods Enzymol 113: 484-490.

18 Hafeman DG, Sunde RA, Hoekstra WG (1974) Effect of dietary selenium on erythrocyte and liver glutathione peroxidase in the rat. J Nutr 104: 580-587.

19 Stocks J, Dormandy TL (1971) The autoxidation of human red cell lipids induced by hydrogen peroxide. Br J Haematol 20: 95-111.

20 Koracevic D, Koracevic G, Djordjevic V, Andrejevic S, Cosic V (2001) Method for the measurement of antioxidant activity in human fluids. J Clin Pathol 54: 356-361.

21 Soltaninejad K, Abdollahi M (2009) Current opinion on the science of organophosphate pesticides and toxic stress: a systematic review. Med Sci Monit 15: RA75-90.

22 Guerrero-Beltrán CE, Calderón-Oliver M, Pedraza-Chaverri J, Chirino YI (2012) Protective effect of sulforaphane against oxidative stress: recent advances. Exp Toxicol Pathol 64: 503-508.

23 Crissman JW, Goodman DG, Hildebrandt PK, Maronpot RR, Prater DA, et al. (2004) Best practices guideline: toxicologic histopathology. Toxicol Pathol 32: 126-131.

24 Kikuchi M, Ushida Y, Shiozawa H, Umeda R, Tsuruya K, et al. (2015) Sulforaphane-rich broccoli sprout extract improves hepatic abnormalities in male subjects. World J Gastroenterol 21: 12457-12467.

25 El-Desoky G, Abdelreheem M, AL-Othman A, ALOthman Z, Mahmoud $M$, et al. (2012) Potential hepatoprotective effects of vitamin $E$ and selenium on hepatotoxicity induced by malathion in rats. African J Pharm Pharmacol 6: 806-813.

26 Saxena R, Garg P, Jain DK (2011) In Vitro Anti-oxidant Effect of Vitamin E on Oxidative Stress Induced due to Pesticides in Rat Erythrocytes. Toxicol Int 18: 73-76.

27 Prior RL, Cao G (1999) Antioxidant capacity and polyphenolic components of teas: implications for altering in vivo antioxidant status. Proc Soc Exp Biol Med 220: 255-261.

28 Aita NAA, Hashesh MA, Mohamed AH (2012) Clinicopathological and cytogenetic studies on the ameliorative effect of propolis against profenofos toxicity in rats. Global Veterinaria 9: 669-682.

29 Budin SB, Han KJ, Jayusman PA, Taib IS, Ghazali AR, et al. (2013) Antioxidant Activity of Tocotrienol Rich Fraction Prevents Fenitrothioninduced Renal Damage in Rats. J Toxicol Pathol 26: 111-118.

30 Gultekin F, Delibas N, Yasar S, Kilinc I (2001) In vivo changes in antioxidant systems and protective role of melatonin and a combination of vitamin $C$ and vitamin $E$ on oxidative damage in erythrocytes induced by chlorpyrifos-ethyl in rats. Arch Toxicol 75: 88-96. 